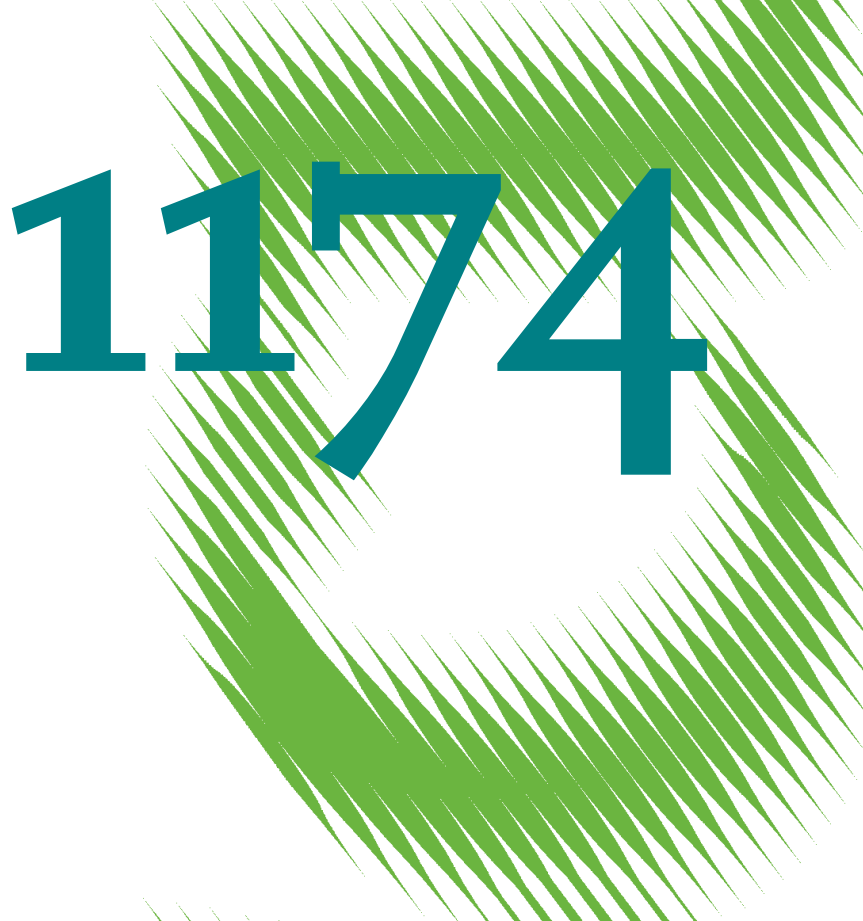

Labor Markets and the Financial Crisis

Evidence from Tajikistan 
Opinions expressed in this paper are those of the author(s) and do not necessarily reflect views of the institute.

IMPRESSUM

(C) DIW Berlin, 2011

DIW Berlin

German Institute for Economic Research

Mohrenstr. 58

10117 Berlin

Tel. $+49(30) 89789-0$

Fax +49 (30) $89789-200$

http://www.diw.de

ISSN print edition $1433-0210$

ISSN electronic edition 1619-4535

Papers can be downloaded free of charge from the DIW Berlin website:

http://www.diw.de/discussionpapers

Discussion Papers of DIW Berlin are indexed in RePEc and SSRN:

http://ideas.repec.org/s/diw/diwwpp.html

http://www.ssrn.com/link/DIW-Berlin-German-Inst-Econ-Res.html 


\title{
Labor markets and the Financial Crisis: Evidence from Tajikistan
}

\author{
Antje Kroeger, Kristina Meier ${ }^{\dagger}$
}

December 7, 2011

\begin{abstract}
The financial crisis in 2008/2009 substantially influenced the everyday social and economic life of many Tajik people, including their behavior in the labor market. However, not much is known about the dynamics of the labor markets of the transition economies, especially in the context of the current financial crisis. Arguably, this is mainly due to paucity of panel data. In this paper, we aim to study the impact of the economic crisis on individual labor market outcomes in Tajikistan. This is the first study investigating the possible impact of the financial crisis in a transition country and uses a unique panel data set from Tajikistan. Although an impact evaluation in the true sense is impossible, due to the lack of a control group, comparing before and after-crisis outcomes can give insights as to how the crisis might have affected labor market outcomes. We do this by calculating transition probabilities between employment categories between 2007 and 2009, using a simple count method as well as predicted probabilities from multinomial probit regressions. Our results suggest an increased probability of moving into unemployment, inactivity or unpaid work during the crisis, with the self-employed being at more risk than the wage employed. This effect is more pronounced for females, as well as for very young and very old individuals. We also find that labor migration (predominantly to Russia) could be a mitigation strategy during the crisis.
\end{abstract}

Keywords: financial crisis, wage employment, migration, Tajikistan

JEL-classification: J24, J16, O10

*DIW Berlin, Mohrenstr.58, 10117 Berlin, Germany, akroeger@diw.de

† Goettingen University, Germany. Acknowledgment: The authors thank the participants of the AEL Conference 2011 in Berlin, the DIAL Development Conference 2011 in Paris, the ERSA conference 2011 in Barcelona and the DIW workshop 2011 in Bishkek, as well as Marc Vothknecht, Stephan Klasen, Susan Steiner and Tony Muhumuza for very helpful comments. 


\section{Introduction}

Since the economic crisis hit in fall 2008 the world has seen one of the worst economic turmoils in history, including both developed and developing countries. Better understanding of how the financial crisis affected different nations is important for the assessment of the consequences of the crisis. Particularly, for policy makers, for several reasons it is important to know how the crisis affected different economies. First, little is known on how an economic crisis affects the living and well-being of individuals and households, especially in poor countries. If consequences are unknown, it is difficult for decision makers to design appropriate support programs for crisis-stricken sectors and people. Second, the analysis of the changes in the country's employment in times of crisis can help design policy reforms that decrease unpaid work or unemployment. Here, the analysis of the labor market is of highest importance. Third, as severe crisis do not occur often, both policy makers and researchers are keen to learn more about the consequences in order to examine ways to overcome the effects of future economic downturns.

There is scant information available concerning the impact of the economic crisis on transition economies. This is especially true for the former Soviet Union economies in Central Asia. As one of the poorest regions in the world, Central Asia was dramatically hit by the financial crisis ICG, 2010, UNDP, 2010, Lukashova and Makenbaeva, 2009. As remittance-dependent countries, not only did these countries experience decreasing remittance inflows, there was also tremendous changes in domestic labor markets ILO, 2010, Tiongson et al. 2010. However, the necessary datasets are scarce. Panel data are necessary when dynamics of the financial crisis in the labor market need to be examined. Individuals and their labor market outcomes, both before and during the crisis, are tracked and investigated.

In the case of Tajikistan, we can draw on unique panel data, using the 2007 and 2009 Tajik Living Standards Measurement Surveys (henceforth, TLSS 2007 \& 2009). Using these rich datasets, we examine individual labor market and household migrant decisions in Tajikistan before and during the crisis. Tajikistan is an interesting case for several reasons. First, Tajikistan is the world's leading remittances receiving country in the proportion of remittances to GDP O'Hara et al. 2009. Secondly, it has a large migrant community abroad. And, thirdly, it is a transition economy significantly influenced by the Russian economy. 
Two core questions are highlighted in this paper. First, does the world economic crisis impact the Tajik labor market? If so, how does the crisis affect individual labor market and migration decisions? In order to answer these key questions, a detailed analysis of the labor market outcomes before and during the crisis is conducted. Specifically, this paper examines the flows from wage employment, self-employment and unpaid work in the Tajik labor market during the crisis, analyzing a nationally representative panel dataset. The analysis focuses on labor market and migration transitions between the end of 2007 and 2009 by estimating Markov chain-style transition probability matrices for different subgroups. To our knowledge, this paper is the first to attempt such an analysis of a Commonwealth of Independent States (CIS) nation. This paper contributes to the academic literature on the consequences of financial crises on the labor market in general and the recent crisis in particular, focusing on the often-neglected Central Asian region.

Our results show that the financial crisis in 2008/2009 had a very strong impact on the Tajik labor market, particularly for women: over 40 percent of women moved out of wage employment during the crisis, while only 30 percent of men left wage employment. Further, 60 percent of women who were selfemployment in 2007 had no paid work in 2009. However, in our paper, we only focus on the possible influence and not on the transmission channels of the financial crisis on labor market outcomes in Tajikistan. We can only measure the "impact" of the crisis by observing the differences between the years. Hence, the observed changes in the labor market are more likely to overestimate the actual impact of the crisis as there might have been other macroeconomic events, such as increases in food prices and high inflation, impacting labor market outcomes.

The remainder of this paper is organized as follows. The next section introduces some background on Tajikistan's economy, labor market and migration. In the third section, we give an overview of the current literature on the impact of the financial crisis in transition countries. In the fourth section, we describe the dataset. Our methodology is explained in section five. Results are presented and discussed in the sixth section, while section seven concludes. 


\section{Background on Tajikistan}

\subsection{Economic Transition and Crisis}

Although Tajikistan enjoyed economic growth between 2005 and 2008, it remained the poorest state in Central Asia. More than half of its population lives below the national poverty line. Compared to its wealthier neighbors, Tajikistan has limited natural resources, principally aluminum [CIA, 2010], on which the economy relies heavily. There is also substantial cotton grown in the country.

After the collapse of the Soviet Union and its planned economy in 1991, Tajikistan experienced a long period of economic contraction [ILO, 2008]. The Tajik commodity specialization on aluminum and cotton has not changed significantly, even with the change in governance. Currently, the major consumer and importer is Russia [CIA, 2010]. Hence, during the 1998/1999 global financial crisis, Tajikistan heavily felt the Russian economic downturn Robson, 2006]. The financial crisis in 2008/2009 mostly hit through falling labor demand in Russia and weak external demand for its export commodities, aluminum and cotton ADB, 2010.

A sharp reduction in workers' remittances, mainly due to economic difficulties in Russia, along with weak demand for Tajikistan's main export commodities of aluminum and cotton were the major factors slowing Tajik GDP growth by more than half in 2009 (see Figure 1). Industrial production, making up about 30 percent of GDP, contracted by 6.3 percent ADB, 2010. Together with falling remittance inflows, this wracked private consumption, import demand, and house construction, especially in rural areas, where many households depend on remittances and cotton production. The International Monetary Fund (IMF) estimated that the poverty rate rose by 5 percentage points during 2009 Kiyoshi and Kakhorjon, 2010.

\subsection{Labor Market, Gender disparities and Migration in transition}

The country's labor market changed dramatically during Tajikistan's transition from a planned to a market economy [ILO, 2008]. Since independence in 1991, decreasing production by, and closure of, state-owned companies led to massive job losses. Unemployment and under-employment are the major push factors encouraging emigration from Tajikistan. Within the Commonwealth of Independent States (CIS), Tajikistan is the country with the lowest average 
monthly income Olimova and Bosc, 2003]. Olimova and Bosc 2003 find that 14.5 percent of all interviewed migrants have never worked before leaving the country, thus indicating that poor labor prospects in the country spur migration. Without large emigration flows mainly toward Russia and Kazakhstan, in 2006, unofficially, unemployment in Tajikistan was estimated to be as high as 40 percent, and in rural areas, it was estimated to exceed 60 percent FRD 2007.

Related both to the condition of labor migration and social attitudes, there is severe gender-segmentation in the labor force, with women working in the lowerpaid sectors of agriculture, education, and health care [JICA, 2008]. There is also an overall decreasing level of involvement of women in the formal labor force. Under Soviet rule, $70 \%$ of all adult women and $78 \%$ of all adult men were employed. In 2003, 70 percent of men and 45 percent of women were in the workforce ADB, 2010]; in 2008, the figures had shifted to 58 percent of men and 31 percent of women. There is also a substantial wage gap between men and women (TLSS 2009).

According to the Statistical Agency under the President of the Republic of Tajikistan (TAJSTAT), the majority of women work in agriculture, jobs that lack both secure employment and social protection. Further, agricultural jobs earn low salaries. , with women earning just under half of what men earn [JICA, 2008. Womens' involvement in agriculture is extensive, however women largely participate as workers rather and not as managers. Despite reforming land laws and rules about the formation of individual or family farms that were a product of the breakup of the Soviet collective farms, women are only a small minority of family farm owners and managers. Often women are not aware of their rights, which were granted when the laws were reformed [USAID, 2010]. Further, stable income in the agricultural sector is strongly linked with the right to own land. However, most land is owned by men, leaving women disadvantaged. The low educational attainment of women also influences their economic activities. Due to existing gender discrimination, employers are reluctant to employ women and prefer employing men as they fear additional costs related to hiring women; for example maternal leave [ILO, 2008]. Men are almost twice as likely as women to be employed by more profitable private companies [Falkingham, 2000] As employment in this sector is traditionally better paid than public sector jobs in, for instance, government educational and health care institutions, women often find themselves economically dependent on their husband's income, thus 
resulting in increased vulnerability [ILO, 2008]. This behavior forces women into informal employment or family work with its limited access to social protection schemes [LO, 2008.

\section{Related Literature}

There is little empirical evidence on the impact of an economic crisis on the labor market in poor countries.

Dimova et al. 2005] address the labor dynamics of the pre- and post- 1996 crisis in Bulgaria, using a panel constructed from the 1995 and 1997 Bulgarian Integrated Household Surveys and a Markov chain model of job mobility. Their results support the hypothesis of a substantial shrinkage of the public sector and movement out of the labor force during the crisis.

Blunch and Sulla, 2011 show that females are disadvantaged in the Serbian labor market in terms of moving out of the two undesirable states, unemployment and economic inactivity, relative to males during the first year of the financial crisis. By estimating Multinomial Logit and OLS regressions, their overall results hint at both males and females being hit in terms of employment and earnings during the crisis.

[McKenzie, 2004 studies the short-term effect of the 2002 financial crisis on households in Argentina and their labor market responses. His results show that young workers and construction workers are the most likely to leave their jobs and that most households experience real income declines during the crisis period.

There is more evidence on the impact of the economic crisis on international migration in Tajikistan.

Danzer and Ivaschenko 2010 show that the economic recession in Russia strongly effects Tajikistan through decreasing remittances flows. They find that the stock of migrants increased during the economic recession: compared to pre-crisis migration rates, more migrants left Tajikistan in 2009 to seek for employment chances abroad, mainly in Russia. Ivakhnyuk 2009b concludes that the Russian labor market, which grew quickly before the crisis, faced reduced demand for labor during the crisis and this, in turn, encouraged the shadow market and made labor less expensive for employers. Thus, not only Russians but also the large number of labor migrants working in Russia were affected by the crisis. 
Studying the impact of the crisis in the Kyrgyz Republic, a study by the OECD concludes that the Russian Federation toughened its migration legislation, which affected migrants in several ways: first, Russia introduced quotas for foreign labor force; second, the Russian legislative complicated the procedures for legal employment; and, third, Russia introduced a 30 percent income tax for non-Russian citizens (compared to 13\% income tax for Russian citizens) Lukashova and Makenbaeva, 2009.

\section{Data}

For our empirical analysis we use two waves from the Tajikistan Living Standard Survey (TLSS), which uses a two-stage sample design and is representative at the national, as well as the rural and urban levels. The sampling frame is based on the 2000 Census of Tajikistan. The questionnaires for 2007 and 2009 surveys are comparable and were designed as individual panel survey. The surveys were prepared by the World Bank in collaboration with UNICEF and carried out by the Statistical Agency under the President of the Republic of Tajikistan (TAJSTAT). The surveys include data on the socio-demographic composition of the household, labor market activities, the health and education of individuals, transfers to the household from various sources and a very detailed module on migrants in the household.

Well before the financial crisis, the first wave was collected between September and November 2007, and comprised of a total of 4,500 households and 32,000 individuals. In late 2009 (October and November), a randomly drawn subsample of these households (totaling to 1,503 households and 7,000 individuals) were reinterviewed. The subsample again was chosen to be representative at the national, as well as rural and urban levels. The TLSS only tracks individuals who stayed in their families over the two years in Tajikistan. The TLSS does not track migrants, regardless of their status in 2007 and 2009.

We restrict our sample to all working-age men and women between 14 and 65 years of age. After strictly balancing the panel, we are left with 3,047 individuals for each year 1 .

\footnotetext{
${ }^{1}$ Note that the balancing does not affect the representativeness of the sample
} 


\section{Methodology}

The main goal of this paper is to shed light on the influence of the financial crisis on labor market outcomes in Tajikistan. An impact evaluation in the true sense of the word is not possible, since the counterfactual situation with an absence of the crisis obviously can neither be observed, nor proxied by a control group, since the crisis hit worldwide. That said, we nevertheless think that interesting findings can emerge from describing and comparing the states before and after the crisis in terms of labor market outcomes by estimating transition probabilities and (multinomial) probit regressions.

As previously mentioned, labor migration plays an important role in Tajikistan. In our analysis we assume the decision to migrate abroad for work is different from the other labor market decisions investigated here, which is why we examine them separately. First, we investigate the labor market decisions of individuals in the domestic labor market. Then, we analyze the household decision to send a migrant abroad.

\subsection{Analysis of labor market outcomes at home}

The analysis of labor market outcomes other than migration abroad is conducted at the individual level, assuming that this is where labor decisions at home are made. The subsample used includes only individuals from non-migration households, since sending a migrant abroad most likely has a significant influence also on the labor outcomes of the remaining household members. Not only must the costs of sending someone abroad be compensated, but family members also have to replace the missing person's labor. Due to its endogenous nature, a dummy indicating a migrant household cannot be included in the analysis. Since we did not find a suitable instrument, we resort to a separate analysis.

In our analysis of the domestic labor market, we look at four labor market outcomes: the dummy "no paid work" is one if an individual is either unemployed, inactive or a unpaid family worker ${ }^{2}$. The dummy "wage-employed" includes regular and piece-based employees and equals one if the individual is

\footnotetext{
${ }^{2}$ We tried to construct unemployment and inactiveness dummies, respectively, but sample sizes are too small for a meaningful distinction. Further, we have reason to believe that the reported unemployment is largely underestimated, as in many other poor countries (see Literature Review) Karnite, 2010.
} 
engaged in wage employment. The dummy "self-employed" equals one if the individual is engaged in any self-employment activity.

In a first step, transition probabilities ${ }^{3}$ between the labor market outcomes "no paid work", "wage-employed" and "self-employed" between 2007 and 2009 are calculated using a straightforward and simple count method. Where cell population permits, we further divide the category "wage employed" into "regular wage employed" and "piece-wise wage". With $k$ states in both years, the transition probability matrix has the dimension $k \times k$ where the element $p_{l m}$, denoting the probability to move from state $l$ to state $m$ is given by:

$$
p_{l m}=\frac{n_{l m}}{\sum_{m} n_{l m}}
$$

with $n_{l m}$ denoting the number of individuals who were in state $l$ in 2007 and moved to state $m$ in 2009. The denominator therefore is the sum over all individuals who were in state $l$ in 2007.

To refine the analysis, these transition probabilities are calculated for different subgroups, according to age, gender and income quantile, and then compared. In a second step, the transition probability matrices are calculated using a multinomial probit model. The advantage here lies in the fact that covariates can be included in the estimation of the transition probabilities.

In the multinomial probit model it is assumed that the utility an individual $i$ derives from choosing alternative or category $k$ is a latent variable $y_{i k}^{*}$ described by

$$
y_{i k}^{*}=\boldsymbol{x}_{i}^{\prime} \boldsymbol{\beta}_{k}+\epsilon_{i k}
$$

Other than with the multinomial logit model, the error terms $\epsilon_{i k}$ are assumed to be multivariate normally distributed and are allowed to be correlated across categories, thus avoiding the assumption of independence of irrelevant alternatives (IIA), which can cause problems when using a multinomial logitt The multinomial probit regression is run on the 2009 labor outcomes, divided

\footnotetext{
${ }^{3}$ The concept of transition probability matrices is taken from the analysis of Markov chains. In our context, however, we only observe two time-periods, with an external shock (i.e. the financial crisis) between them. Therefore our interest is not to estimate the parameters of a Markov chain, but to merely descriptively investigate the transition between 2007 and 2009.

${ }^{4}$ Tests have indicated that IIA might be problematic for the data at hand.
} 
into different subsamples determined by the labor outcome of the individual in 2007. In other words, this means that the first subsample consists of the 2009 outcomes of those who were without paid work in 2007 (with "no paid work" being the base category against which the other outcomes are evaluated). The second subsample consists of the 2009 outcomes of those who were wage employed in 2007 (with "wage employed" being the base category against which the other outcomes are evaluated) and the third subsample consists of those who were self-employed in 2007 (with "self-employed" being the base category against which the other outcomes are evaluated). The transition probabilities $p_{l m}$ are then estimated as the predicted probability of choosing state $k$ over the base category.

\subsection{Analysis of labor migration}

As already mentioned above, the decision to migrate abroad is assumed to take place at the household level, therefore transition probabilities into and out of labor migration are estimated on the household level. The methods used are the same as for the domestic labor market, only the number of possible states reduces to two (namely "household has at least 1 labor migrant" and "household has no labor migrant"). Unfortunately, additional descriptive analyses of labor migration on the individual level are not possible, since the data do not allow for tracking of migrants between the two years. Only individuals who stayed in Tajikistan for both years can be tracked, thus limiting the possibilities of analysis.

\section{$6 \quad$ Results}

\subsection{Labor market outcomes at home}

\subsubsection{Descriptives}

Table 3 shows the percentages of different labor market outcomes for both 2007 and 2009. The first panel combines the figures for both men and women, and shows a significant increase in the percentage of individuals without paid work (as already mentioned this category includes unemployed, inactive, as well as unpaid work). Furthermore, a noticeable decrease in regular wage work can be observed. Wage employment on a piece wise basis seems to have increased, 
while self-employment decreased, however, both differences over the year are not significant according to the two-sample t-test applied.

When looking at panel 2 and 3, which display the percentages for men and women respectively, it becomes clear that the decrease in regular wage employment, as well as the slight increase in employment on a piece-wise basis is mainly driven by female labor market force. Since the percentage of women without paid work is traditionally high in Tajikistan [JICA, 2008, no significant change in female unpaid work is observed between 2007 and 2009. Hence, the increase in individuals engaged in unpaid work is mostly driven by men.

Some of these changes in the employment structure might be explained by the fact that regular wage employment decreases during times of crisis as companies, struggling with decreasing demand, aim to keep their fixed-costs, including wages, as low as possible. Further, the probability to be in an irregular wage employment increases as agreements become short-term and employees do not aim to commit themselves to a long-term employment contract. Overall, selfemployment might decrease due to increased risk of running an own little shop or business. In line with the literature, we find that most women engage in unpaid work [JICA, 2008.

\subsubsection{Estimation of transition probabilities}

First, transition probabilities are calculated using the simple count method outlined above. Table 4 shows the transition matrices for the full sample and for men and women, respectively. 5 Our results indicate that "no paid work" seems to be a fairly persistent state: approximately 80 percent of those out of paid work before the onset of the crisis in 2007 remain so in 2009. As expected, this effect is stronger for females than for males. Around 60 percent of those wage-employed in 2007 manage to keep this employment status in 2009, however, 30-40 percent move out of paid work during the crisis. Again, females are hit harder than males. The most unstable state seems to be self-employment, with transition probabilities into unemployment, inactiveness or unpaid work as high as almost 60 percent for women and around 34 percent for men. However, it has to be noted that there is also a considerable percentage moving from self-employment into wage-employment during the crisis. A general interpreta-

\footnotetext{
${ }^{5}$ Since the sample is quite small, the categories "regular wage" and "piece-wise wage" were combined to ensure sufficient cell population. Nevertheless, since only very few females are self-employed, there still remain some scarcely populated cells. Resulting estimates should be treated with caution.
} 
tion is that during the crisis, entrepreneurship became more risky, hence, those involved in self-employment rather chose to look for wage work because of risk aversion.

If only men, as well as both genders together are investigated, the data permits repetition of the above estimations differentiating between regular wage employment and employment on a piece-wise basis. (For females alone, cell populations are too small to yield meaningful results). These results are shown in Table 5. Here it can be seen that the increased transition probability from selfemployment into wage employment is mostly due to an increase in piece-wise, rather than regular wage employment. This is also in line with our descriptive statistics.

To investigate the influence of age and wealth (measured as per capita expenditure quintiles in 2007) on the transition probabilities, outcome categories had to be reduced to "no paid work" or "paid work", due to insufficient cell populations. The results can be seen in Figures 2 and 3. The characteristic, ushaped relation between age and employment presents itself clearly. Very young people, as well as those close to retirement, have a noticeably higher probability of moving from paid work into unemployment, inactiveness or unpaid work in 2009. This is not a surprising result, considering the fact it is harder to find a job when reaching old age in most places.

Further, we also calculate transition probabilities for the different expenditure quintiles in 2007. As seen in Figure 3, the results suggest no noticeable differences, suggesting that the effects of the economic turmoil was not just limited to poor families.

In a second step, we run a multinomial probit regression estimating the transition probabilities, including explanatory variables on the individual, household and community levels in 2007 (Tables 1 and 2). The following model was fitted:

labor status in $2009=\alpha+\beta_{1}$ age $+\beta_{2} a g e^{2}+\beta_{3}$ gender +

$$
\begin{gathered}
\beta_{4} \text { knowrussian }+\beta_{5} \text { secondaryeducation }+\beta_{6} \text { dependencyratio }+ \\
\beta_{7} \text { location }+\beta_{8} \text { altitude }+\beta_{9} \text { materialsector } 07+
\end{gathered}
$$




$$
\beta_{10} \text { percentagewageemployed }+\beta_{11} \text { hhhead }+\epsilon
$$

The resulting transition probabilities are quite similar to those obtained using the simple count method. Tables 8 to 10 show the transition probabilities, as well as the marginal effects of the covariates. As already expected after the preceding analysis, age (even after accounting for its nonlinear relationship with the outcome) seems to have a positive effect on being engaged in paid work (i.e. wage-employed or self-employed), however the effect of age is only significant when the initial labor status (in 2007) is "no paid work". An exception is observed for the initial state of self-employment. Here, age seems to be negatively associated with the probability of staying in paid labor. However, due to the small sample size (only 265 individuals were self-employed in 2007), results need to be interpreted with caution.

Being male has a clear positive effect on the probability of moving into or staying in paid labor. There is also a significant effect of language skills: The effect of knowing Russian seems to positively affect the chances of wage employment (however, coefficients are sometimes insignificant).

Coming from high-altitude areas negatively influences the probability of having a paid job, which makes sense, considering poorer infrastructure and overall worse living conditions in the highlands. However, the effect is usually quite small and often not significant. Living in an urban area has a negative effect on being in paid employment, which is not intuitive and needs further investigation. One possible explanation might be that finding a job in agriculture, which is not an option in an urban setting, might be comparatively easier.

The sector of individual's employment prior to the crisis seems to have a strong influence on 2009 labor status outcomes. Previous work in the material (i.e. the producing) sector has a significant negative effect on remaining in wage employment. This reflects the fact that the producing sector of Tajikistan was hit especially hard by the crisis, since it relies on exports. While the effects of the dependency ratio within the household, as well as whether an individual has at least secondary education are somewhat ambiguous, there seems to be a clear pull-effect of the intra-household percentage of wage-employed ${ }^{6}$ Apparently having other family members in wage-employment increases the probability of being wage-employed oneself. It does make sense to assume that finding a job in

\footnotetext{
${ }^{6}$ This variable is calculated as the percentage of all work-aged household members in wageemployment, excluding the current individual
} 
a company or with the government is easier if some family member already has his or her foot in the door. This effect is especially pronounced for the subsample of those self-employed in 2007. However, the magnitude of the coefficient should be interpreted with caution, since the sample size is quite small.

Finally, being the household head also seems to have a positive influence on staying in or moving into paid work. Maybe this can be explained with the increased pressure to provide for the family. It could also be that the family identified the main bread winner as the head in the questionnaire.

\subsection{Analysis of labor migration}

\subsubsection{Descriptives}

Table 7 compares percentages of households without, with one, or with more than one labor migrants both before and after the crisis. We define a migrant household as a family which at some point during the last 12 months had at least one household member who went abroad to work. This definition includes both those migrants that already returned, as well as those currently away. The subsample of households with a migrant in 2007 contains only 366 observations, hence, our results for this group should be interpreted with caution.

Table 7 reveals a significant increase in migrants from 2007 to 2009, not only for one migrant but also for two or more. This is in line with the literature Marat, 2009, Ganguli, 2009, Danzer and Ivaschenko, 2010. A possible explanation for this development could be that households are trying to cope with the crisis at home by sending family members abroad to work (see, for example, Brown et al. 2008). Migration and remittances might be regarded as a substitute for wage employment in Tajikistan, where those members who have become migrants (and are now sending remittances) are the same individuals who would otherwise be working in the domestic economy as wage employees. It has to be taken into account that the crisis hit worldwide, therefore the economy in the migrants' countries of destination (mostly Russia) also suffered, and most likely restrictions were placed on labor immigration, as well as wages earned by migrants. So, it could have been the case that migrant workers received reduced wages abroad, which made increased migration from Tajikistan necessary.

Therefore it makes sense to assume that families were obliged to send more migrants in order to receive sufficient returns. Russia tightened regulations regarding labor migrants Ivakhnyuk, 2009a, making it more difficult for Tajik

migrant workers to find work and earn enough money. The results in Table 6 
give tentative evidence for this, showing a significant, yet rather small increase in pre-arranged jobs (to better cope with tightened labor market regulations), as well as in expulsions from the host country due to legal issues (involving work permits, etc.).

The most likely reason for this is the reduced wage received by migrant workers abroad, which makes increased migration necessary. The descriptives

in Table 7 also hint in this direction. Another possible explanation is that during the financial crisis finding work at home in Tajikistan was even more difficult than working abroad.

\subsubsection{Estimation of transition probabilities}

Again, transition probabilities are estimated using the simple count method, as well as the predicted probabilities, in this case from a probit model (since the outcome ("HH has at least one migrant, yes/no") is binary). Here, a similar model as in the previous section is fitted. However, since we estimate the decision to send a household member abroad at the household level, we adjust our covariates. We control for the sex and education ratio in the household, characteristics of the household head (age and education) and for farmland, received transfers, dependency ratio and working-age individuals in the household.

Table 11 shows the results (those derived from the simple count method are again quite similar and are therefore omitted). As expected after looking at the descriptive results, having a migrant is a relatively persistent state, the transition probability of having at least one migrant in 2009 if the household was already a migrant household in 2007 is around $60 \%$. Also, having at least one migrant in 2009 when there were none in 2007 has a relatively high transition probability of approximately $26 \%$.

Table 12 gives the marginal effects of the probit analysis. While the ratio of working-age household members, as well as the gender ratio have the expected positive sign, the working-age ratio is not significant for the subsample of migrant households in 2007. This can be due to the fact that the cell population is very small with only 366 observations. The percentage of family members knowing Russian is significant with the expected positive sign only for the subsample of migrant households in 2007, indicating that families with a better knowledge of the Russian language are more likely to send a household member abroad. The amount of arable land per capita, in theory, has a negative effect 
on sending a household member abroad, since the more land, the more family members are needed to farm it McKenzie and Rapoport, 2007. This is also true for our empirical findings, when the variable land per capita is significant.

\section{Conclusion}

Do macroeconomic shocks impact employment patterns in poor countries? Our aim is to make a first attempt at resolving this question by analyzing the effects of the financial crisis in 2008/2009 on the Tajik labor market, using TLSS panel data from 2007 and 2009. Keeping in mind that our analysis does not have the methodological rigor of an impact analysis that is able to identify causality, our results nevertheless give some interesting clues about possible effects of the crisis on labor market outcomes.

Our results suggest a strong persistence of unemployment, inactivity and unpaid labor (all three combined in the category "no paid work") during the crisis, making the transition to paid work very hard. Here, gender also matters: women are more likely to stay in unpaid jobs or lose their paid employment. Further, transition from paid work into unemployment, inactivity or unpaid labor is more likely for the very young and those already close to leaving the workforce. The data, however, do not show an impact of per capita expenditure quintile in 2007 on this transition probability, which is somewhat surprising. Both wage employment and self employment reduce, where the self-employed seem to be most affected by the crisis, either leaving to unemployment or piece-

wise wage employment. A general explanation for our results is that in times of economic crisis, companies are more reluctant to employ people on a regular contract basis. They often dismiss employees due to falling demand and sales. As a consequence, some individuals cease regular wage employment and start looking for other employment opportunities, resume studying or just stay at home. Secondly, having one's own small business becomes more risky, driving entrepreneurs either into (mostly) piece-wise employment or out of paid work entirely. This pattern is not only true in developed countries, but also seems to be true in the case of one of the world's poorest countries.

The multinomial probit analyses suggest that being male, household head and/or having a high percentage of family members in wage employment all have a positive impact on staying in or moving into paid labor, whereas living 
in mountainous regions or an urban setting reduces this probability. Previously having been employed in the producing sector also has a significant negative effect on the probability of staying in wage employment.

Labor migration, which plays a big role in Tajikistan, is investigated separately and at the household level, since it is assumed that the decision to migrate abroad is made by the household rather than the individual level. Data show an increase in households with at least one labor migrant between 2007 and 2009, suggesting that labor migration may be a mitigation strategy for coping with the effects of the crisis at home in Tajikistan. However, the analysis of labor migration at this point is quite superficial and leaves room for further research.

Concluding, it can be said that although an impact evaluation in the true sense is impossible for the situation at hand, investigation of transition probabilities into different labor market statuses before and after the crisis hint at a worsening of labor market outcomes in Tajikistan during the time of the crisis. Labor migration to Russia, although on average more risky and less lucrative than before the crisis, looks like a possible mitigation strategy.

In our paper, we only focus on the possible influence and not on the transmission channels of the financial crisis on labor market outcomes in Tajikistan. Further research needs to be done on the transmission channels through which workers are affected, as well as the impact of increased migration on welfare and poverty on remaining household members. 


\section{References}

ADB. Tajikistan. Asian Development Outlook 2010. 2010. 2.1,2.2

N. Blunch and V. Sulla. The financial crisis, labor market transitions and earnings: A gendered panel data analysis for serbia. 2011. 3

R. Brown, S. Olimova, and M. Boboev. A study on international migrantsAzf remittances in central asia and caucasus: Country report on remittances of international migrants in tajikistan, 2008. 6.2.1

CIA. Central Interlligence Agency (CIA). 2010. World Factbook. https : //www.cia.gov/library/publications/the - world - factbook/; last access July,7, 2010. 2.1

A. Danzer and O. Ivaschenko. Migration patterns in a remittances dependant economy: Evidence from tajikistan during the global financial crisis. Migration Letters, 2010. $3,6.2 .1$

R. Dimova, I. Gang, J. Landon-Lane, and W. I. for Development Economics Research. The informal sector during crisis and transition. United Nations University, World Institute for Development Economics Research, 2005. 3

J. Falkingham. Women and gender relations in Tajikistan. Asian Development Bank, Programs Dept. East and Office of Environment and Social Development, 2000. 2.2

FRD. Library congress-federal research division (frd. country profile: Tajikistan. 2007. 2.2

I. Ganguli. Tajik labor migration to Russia: Is Tajikistan at a crossroad? 2009. 6.2 .1

ICG. International Crisis Group. Central Asia: Migrants and the Economic Crisis Asia Report Nr.183. 2010. 1

ILO. Work and Family: The Republic of Tajikistan. 2008. 2.1, 2.2

ILO. Key issues in the labour market: 1.Economic crisis and labour market impacts. 2010. 1

I. Ivakhnyuk. Closed and Open Doors for Labor Migrants. International Affairs, (005):74-82, 2009a. 6.2.1 
I. Ivakhnyuk. The Russian Migration Policy and its Impact on Human Development: The Historical Perspective. United Nations Development Programme, 2009b. 3

JICA. JICA Tajikistan Office 2008. Tajikistan Gender Profile. 2008. 2.2, 6.1.1

R. Karnite. Technical assistance to sector policy support programme in the social protection sector labour policy component. analysis of the current situation of the labour market in tajikistan. 2010. 2

T. Kiyoshi and A. Kakhorjon. Tajikistan. 2010. 2.1

I. Lukashova and I. Makenbaeva. Impact of the Global Financial Crisis on Labour Migration from Kyrgyzstan to Russia Qualitative overview and quantitative survey. 2009. 1, 3

E. Marat. Shrinking remittances increase labor migration from Central Asia. Central Asia-Caucasus Analyst, 2009. 6.2.1

D. McKenzie. Aggregate shocks and urban labor market responses: evidence from argentina's financial crisis. Economic Development and Cultural Change, 52(4):719-758, 2004. 3

D. McKenzie and H. Rapoport. Network effects and the dynamics of migration and inequality: theory and evidence from mexico. Journal of Development Economics, 84(1):1-24, 2007. 6.2 .2

S. O'Hara, A. Ivlevs, and M. Gentile. The Impact of Global Economic Crisis on Remittances in the Commonwealth of Independent States. Eurasian Geography and Economics, 50(4):447-463, 2009. 1

S. Olimova and I. Bosc. Labour migration from Tajikistan. International Organization for Migration, 2003. 2.2

M. Robson. Estimating Russia's Impact on the Economic Performance of the Commonwealth of Independent States since 1991: The Cases of the Kyrgyz Republic, Tajikistan, Armenia, Georgia and Ukraine. Overseas Development Institute, London, ESAU Working Paper, 16, 2006. 2.1

E. Tiongson, N. Sugawara, and V. Sulla. The crisis hits home: stress-testing households in Eastern Europe and Central Asia. World Bank Publications, 2010. 1 
UNDP. The Human Development Report. Overcoming barriers: human mobility and development. 2010. 1

USAID. Gender Assessment. USAID/Central Asian Republics. Kazakhstan, Kyrgyzstan, Tajikistan, Turkmenistan, Uzbekistan. 2010. 2.2

\section{Tables}


Table 1: Definition of Variables

\begin{tabular}{l|l}
\hline \hline Name of Variable & \\
\hline age & Age of the person \\
sex & One if male, zero if female \\
know_russian & Dummy indicating whether person knows Russian \\
edu_sec & Dummy indicating whether person has at least secondary education \\
material_07 & Total amount of educational expenditures \\
& Dummy indicating whether person worked \\
& in the material (productive) sector in 2007 \\
\hline no paid work & One if person is either unemployed, has no paid work or is inactive \\
wage regular & One if person has regular wage employment \\
wage piece & One if person has piece-based wage employment \\
self-employed & One if person is self-employed \\
\hline Household Level & \\
dep_ratio & Dependency ratio within the hh \\
location & One if household lives in urban area, zero if rural \\
tajik & One if household lives is tajik, zero if otherwise \\
altitude & Indicating altitude in which household resides \\
trans_cash & Dummy indicating whether hh has access to additional \\
& financing (through friends/relatives) \\
plot_pc & Per capita acreage of farmable land for each hh member \\
r_workage & Ratio of working-age people within hh \\
r_sex & Gender ratio within hh \\
r_edu_sec & Ratio of people with at least secondary education within hh \\
\hline migrant & One if household has a migrant within the last 12 months \\
\hline \hline
\end{tabular}


Table 2: Summary Satistics for Regressors

\begin{tabular}{lcccc}
\hline \hline & mean & sd & min & max \\
\hline Individual Level & & & & \\
age & 34.9232 & 13.67659 & 14 & 65 \\
sex & .4850673 & .499818 & 0 & 1 \\
know_russian & .5782737 & .4938757 & 0 & 1 \\
edu_sec & .7302265 & .4438785 & 0 & 1 \\
dep_ratio & .5686921 & .5660815 & 0 & 5 \\
urban & .3672465 & .482094 & 0 & 1 \\
altitude & 853.4992 & 485.1448 & 308 & 3861 \\
material & .3009518 & .4587094 & 0 & 1 \\
\hline$N$ & 6094 & & & \\
\hline \hline Household Level & & & & \\
r_workage & .6685156 & .2328606 & 0 & 1 \\
r_sex & .4914648 & .1766429 & 0 & 1 \\
r_edu_sec & .4898618 & .2576771 & 0 & 1 \\
trans_cash & .083612 & .2768514 & 0 & 1 \\
farmland_pc & 3.257649 & 10.42101 & 0 & 175.75 \\
r_know_russian & .4274777 & .3228594 & 0 & 1 \\
tajik & .7541806 & .430644 & 0 & 1 \\
altitude & 917.2836 & 579.3367 & 308 & 3861 \\
\hline$N$ - & 2990 & & & \\
\hline \hline
\end{tabular}


Table 3: Individual Labor Market characteristics

\begin{tabular}{lccccc}
\hline \hline & 2007 & $\mathrm{~N}$ & 2009 & $\mathrm{~N}$ & $09-07$ Sign. \\
\hline All & & & & & \\
no paid work & 0.580 & 1789 & 0.608 & 1862 & $0.029^{* *}$ \\
wage regular & 0.214 & 631 & 0.180 & 545 & $-0.034^{* * *}$ \\
wage piece & 0.117 & 357 & 0.135 & 401 & 0.017 \\
self-employed & 0.089 & 265 & 0.077 & 234 & -0.012 \\
\hline Men & & & & & \\
no paid work & 0.423 & 637 & 0.461 & 681 & $0.038^{* *}$ \\
wage regular & 0.262 & 380 & 0.239 & 345 & -0.024 \\
wage piece & 0.187 & 271 & 0.194 & 287 & 0.008 \\
self-employed & 0.127 & 186 & 0.106 & 161 & -0.022 \\
\hline Women & & & & & \\
no paid work & 0.726 & 1152 & 0.746 & 1181 & 0.020 \\
wage regular & 0.168 & 251 & 0.124 & 200 & $-0.044^{* * *}$ \\
wage piece & 0.052 & 86 & 0.079 & 114 & $0.026^{* *}$ \\
self-employed & 0.053 & 79 & 0.051 & 73 & -0.002 \\
\hline \hline
\end{tabular}

${ }^{*} p<0.10,{ }^{* *} p<0.05,{ }^{* * *} p<0.01$ 
Table 4: Transition Probabilities 1

\begin{tabular}{lcccccc}
\hline \hline & no paid work & $\mathrm{N}$ & wage & $\mathrm{N}$ & self empl & $\mathrm{N}$ \\
\hline All & & & & & & \\
no paid work & 0.797 & 1445 & 0.141 & 249 & 0.061 & 95 \\
wage & 0.332 & 311 & 0.593 & 597 & 0.075 & 80 \\
self-employed & 0.417 & 106 & 0.371 & 100 & 0.212 & 59 \\
\hline Men & & & & & & \\
no paid work & 0.679 & 440 & 0.236 & 149 & 0.085 & 48 \\
wage & 0.295 & 181 & 0.607 & 400 & 0.098 & 70 \\
self-employed & 0.339 & 60 & 0.444 & 83 & 0.216 & 43 \\
\hline Women & & & & & & \\
no paid work & 0.862 & 1005 & 0.090 & 100 & 0.048 & 47 \\
wage & 0.403 & 130 & 0.566 & 197 & 0.030 & 10 \\
self-employed & 0.593 & 46 & 0.204 & 17 & 0.203 & 16 \\
\hline \hline
\end{tabular}

${ }^{*} p<0.10,{ }^{* *} p<0.05,{ }^{* * *} p<0.01$ 
Table 5: Transition Probabilities 2

\begin{tabular}{lcccccccc}
\hline \hline & no paid work & $\mathrm{N}$ & wage reg & $\mathrm{N}$ & wage piece & $\mathrm{N}$ & self-empl & $\mathrm{N}$ \\
\hline All & & & & & & & & \\
no paid work & 0.797 & 1445 & 0.072 & 122 & 0.070 & 127 & 0.061 & 95 \\
wage regular & 0.307 & 182 & 0.478 & 322 & 0.167 & 94 & 0.048 & 33 \\
wage piece & 0.378 & 129 & 0.190 & 61 & 0.308 & 120 & 0.124 & 47 \\
self-employed & 0.417 & 106 & 0.168 & 40 & 0.202 & 60 & 0.212 & 59 \\
\hline Men & & & & & & & & \\
no paid work & 0.679 & 440 & 0.113 & 66 & 0.123 & 83 & 0.085 & 48 \\
wage regular & 0.246 & 90 & 0.503 & 200 & 0.191 & 64 & 0.060 & 26 \\
wage piece & 0.363 & 91 & 0.189 & 46 & 0.296 & 90 & 0.152 & 44 \\
self-employed & 0.339 & 60 & 0.201 & 33 & 0.243 & 50 & 0.216 & 43 \\
\hline \hline
\end{tabular}

${ }^{*} p<0.10,{ }^{* *} p<0.05,{ }^{* * *} p<0.01$ 
Table 6: Individual migration characteristics

\begin{tabular}{lccc}
\hline \hline & 2007 & 2009 & $09-07$ Sign. \\
\hline Job pre-arranged & & & \\
Yes & 0.155 & 0.236 & 0.080 *** \\
No & 0.845 & 0.764 & \\
\hline Kicked out & & & \\
Yes & 0.027 & 0.098 & 0.071 *** \\
No & 0.973 & 0.902 & \\
\hline \hline$p<0.10, * * p<0.05, * * * p<0.01$ &
\end{tabular}

Table 7: HH-Level Migration

\begin{tabular}{lccccc}
\hline \hline & 2007 & $\mathrm{~N}$ & 2009 & $\mathrm{~N}$ & $09-07$ Sign. \\
\hline No of migr & & & & & \\
zero & 0.745 & 3703 & 0.655 & 982 & $-0.091^{* * *}$ \\
one & 0.196 & 896 & 0.248 & 365 & $0.052^{* * *}$ \\
two and more & 0.059 & 261 & 0.097 & 148 & $0.038^{* * *}$ \\
\hline \hline
\end{tabular}

${ }^{*} p<0.10,{ }^{* *} p<0.05,{ }^{* * *} p<0.01$ 
Table 8: Multinomial Probit Model: Labor outcomes in 2009 if no paid work in $\underline{2007}$

\begin{tabular}{lccc}
\hline \hline & $(1)$ & $(2)$ & $(3)$ \\
\hline \hline migrant & no paid work & wage employed & self-employed \\
\hline age & $-.005^{* * *}$ & $.003^{* * *}$ & $.001^{* * *}$ \\
sex & $-.160^{* * *}$ & $.127^{* * *}$ & $.032^{* *}$ \\
knowing Russian & -.023 & $.044^{* *}$ & -.021 \\
secondary edu & .018 & $-.036^{*}$ & .018 \\
dependency ratio & $.039^{*}$ &.-013 & $-.026^{* *}$ \\
location & $.070^{* * *}$ & $-.071^{* * *}$ & .011 \\
altitude & $.0001^{* *}$ & $-.0001^{* *}$ & -.00002 \\
per of wage empl & -.054 & $.171^{* * *}$ & $.117^{* * *}$ \\
hh head & -.100 & $.081^{* * *}$ & .019 \\
\hline \hline Predicted probabilities & .800 & .141 & .059 \\
$N$ & 1789 & 1789 & 1789 \\
\hline \hline
\end{tabular}

Marginal effects

${ }^{*} p<0.10,{ }^{* *} p<0.05,{ }^{* * *} p<0.01$ 
Table 9: Multinomial Probit Model: Labor outcomes in 2009 if sef-employed in2007

\begin{tabular}{lccc}
\hline \hline & $(1)$ & $(2)$ & $(3)$ \\
\hline \hline migrant & no paid work & wage employed & self-employed \\
\hline age & $.008^{* *}$ & $-.010^{* * *}$ & .002 \\
sex & $-.191^{* *}$ & $.256^{* * *}$ &.-066 \\
knowing Russian & .096 & .018 & $-.114^{* *}$ \\
secondary edu & .055 & $-.117^{*}$ & .062 \\
dependency ratio & -.050 & .081 & -.017 \\
location & .031 & $-.144^{* *}$ & $.113^{* *}$ \\
altitude & $.0001^{*}$ & $-.0002^{* * *}$ & .00003 \\
material sector & .014 & -.049 & -.063 \\
per of wage empl & -.235 & $.754^{* * *}$ & $-.520^{* * *}$ \\
hh head & $-.288^{* * *}$ & $.278^{* * *}$ & -.010 \\
\hline \hline Predicted probabilities & .413 & .378 & .209 \\
$N$ & 265 & 265 & 265 \\
\hline \hline
\end{tabular}

Marginal effects

${ }^{*} p<0.10,{ }^{* *} p<0.05,{ }^{* * *} p<0.01$ 
Table 10: Multinomial Probit Model: Labor outcomes in 2009 if wage-employed in 2007

\begin{tabular}{lccc}
\hline \hline & $(1)$ & $(2)$ & $(3)$ \\
\hline \hline migrant & no paid work & wage employed & self-employed \\
\hline age & -.002 & .002 & .0001 \\
sex & -.047 & .017 & $.065^{* *}$ \\
knowing Russian & -.055 & -.021 & $.076^{* * *}$ \\
secondary edu & -.042 & $.093^{* *}$ & $-.050^{* *}$ \\
dependency ratio & -.012 & $.058^{*}$ & $-.046^{* *}$ \\
location & .044 & -.044 & -.0002 \\
altitude & .000 & .000 & .000 \\
material sector & $.095^{* *}$ & $-.117^{* * *}$ & .023 \\
per of wage empl & $-.144^{* *}$ & $.303^{* * *}$ & $-.158^{* * *}$ \\
hh head & $-.148^{* * *}$ & $.165^{* * *}$ & -.017 \\
\hline \hline Predicted probabilities & .327 & .597 & .076 \\
$N$ & 988 & 988 & 988 \\
\hline \hline
\end{tabular}

Marginal effects

${ }^{*} p<0.10,{ }^{* *} p<0.05,{ }^{* * *} p<0.01$ 
Table 11: Transition Probabilities for migration outcomes

\begin{tabular}{lcc}
\hline \hline & no migrant & migrant (1 ore more) \\
\hline no migrant & 0.739 & 0.261 \\
migrant (1 or more) & 0.406 & 0.594 \\
\hline \hline
\end{tabular}


Table 12: Probit Model: Household Decision to send migrant abroad

\begin{tabular}{lcc}
\hline \hline & $(1)$ & $(2)$ \\
migrant & HH with migrant in 07 & HH without migrant in 07 \\
\hline r__workage & .186 & $.821^{* * *}$ \\
r_sex & $(0.38)$ & $(3.94)$ \\
& $1.32^{* * *}$ & $.978^{* * *}$ \\
r_edu_sec & $(2.73)$ & $(4.00)$ \\
& .393 & -.0761 \\
trans_cash & $(1.16)$ & $(-0.38)$ \\
& $-.432^{*}$ & .0458 \\
plot & $(-1.87)$ & $(0.32)$ \\
& .00238 & $-.0205^{* * *}$ \\
r_know_russian & $(0.20)$ & $(-4.38)$ \\
& $.758^{* * *}$ & -.207 \\
tajik & $(2.68)$ & $(-1.37)$ \\
& $-.283^{*}$ & -.0346 \\
gbao & $(-1.72)$ & $(-0.30)$ \\
& -.182 & .232 \\
$N$ & $(-0.86)$ & $(1.33)$ \\
\hline \hline
\end{tabular}

Marginal effects; $t$ statistics in parentheses

${ }^{*} p<0.10,{ }^{* *} p<0.05,{ }^{* * *} p<0.01$ 
Figure 1: Gross Domestic Product, Percentage Changes

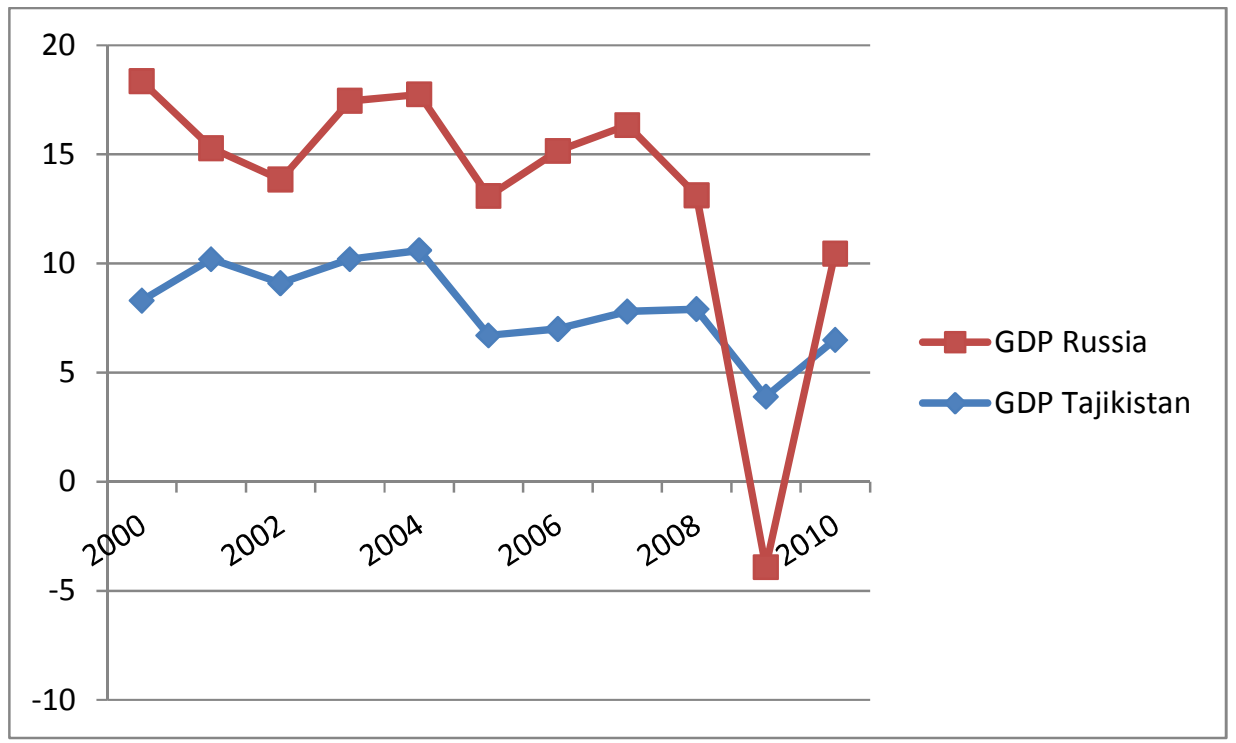


Figure 2: Effect of age on transition probabilities

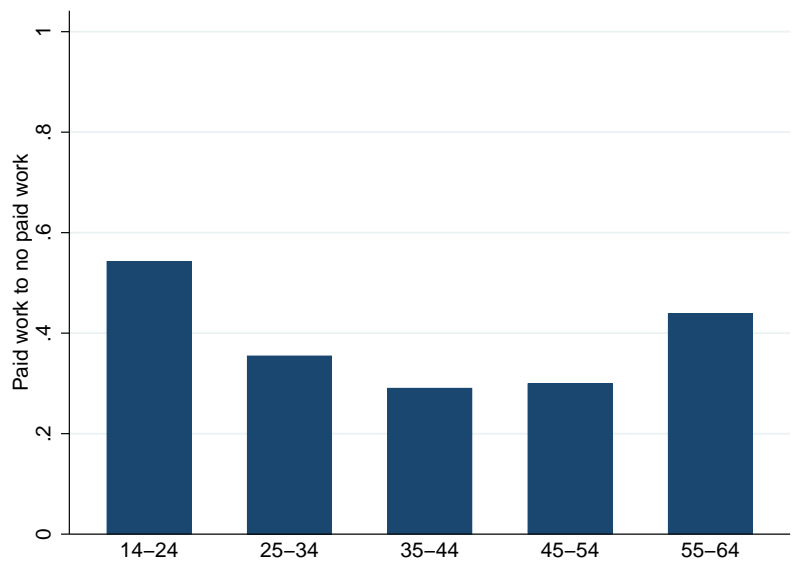


Figure 3: Effect of wealth on transition probabilities

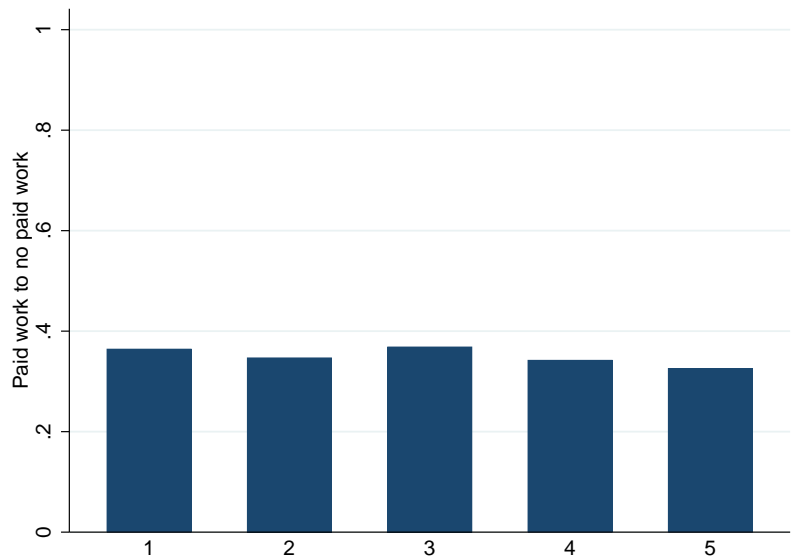

